\title{
Effects of Lactobacillus buchneri NCIMB 40788 and forage: Concentrate ratio on the growth performance of finishing feedlot lambs fed maize silage
}

\author{
Fernanda C. Basso ${ }^{a}$, Carlos H.S. Rabelo ${ }^{a, *}$, Erika C. Lara ${ }^{a}$, Gustavo R. Siqueira ${ }^{a, b}$, \\ Ricardo A. Reis ${ }^{\mathrm{a}}$ \\ a UNESP, São Paulo State University, Department of Animal Sciences, 14884-900, Jaboticabal, SP, Brazil \\ b APTA, São Paulo State Agency for Agribusiness Technology, Alta Mogiana 14770-000, Colina, SP, Brazil
}

\section{A R T I C L E I N F O}

\section{Keywords:}

\section{Corn silage}

Digestibility

Roughage: concentrate ratio

Ruminal fermentation

Silage inoculant

\begin{abstract}
A B S T R A C T
Inoculation of maize silage with Lactobacillus buchneri has improved livestock production in some cases, but the published literature has shown that results depend on the dietary forage: concentrate $(\mathrm{F}: \mathrm{C})$ ratio; however, there is little knowledge on the interaction between the silage inoculant and F:C ratio. Thus, we aimed to investigate the effect of feeding maize silage inoculated with L. buchneri NCIMB 40788 and two F:C ratios on feed intake and growth performance of lambs. Twenty-eight Dorper $\times$ Santa Ines lambs were arranged in a randomized block design ( $n=7$ ) and then assigned to one of four diets as follows: 1 ) untreated maize silage (with no silage inoculant) and low concentrate (400 g/ kg dry matter (DM); US-LC); 2) maize silage inoculated with L. buchneri and low concentrate (400 g/kg DM; IS-LC); 3) untreated maize silage and moderately high concentrate (600 g/kg DM; US-HC); and 4) maize silage inoculated with $L$. buchneri and moderately high concentrate (600 g/kg DM; IS-HC). There was an interaction between inoculation and F:C ratio for DM intake (DMI), in which lambs fed the US-LC diet had lower DMI $(P=0.013)$ than that of all the other diets. Inoculation decreased crude protein $(C P)$ digestibility $(P=0.003 ;-6.1 \%)$. As compared with the LC diet, the HC diet had a lower $(P \leq$ 0.016 ) apparent digestibility of DM, organic matter, and CP. Inoculation increased the average daily gain of lambs $(P=0.022)$ mostly when they were fed the LC diet than that observed for the HC diet. In conclusion, inoculation of maize silage with $L$. buchneri improved lamb production on feeding of diets having a higher proportion of silage, but this response was not accompanied of higher profitability. Additionally, the response of L. buchneri on lamb production is highly dependent of the $\mathrm{F}: \mathrm{C}$ ratio.
\end{abstract}

\section{Introduction}

Lactobacillus buchneri is a heterofermentative lactic-acid bacterium able to convert lactic acid to acetic acid, 1,2-propanediol, and traces of ethanol under anaerobic conditions (Oude Elferink et al., 2001). In livestock, L. buchneri is mostly used to improve the aerobic stability of various silages, by producing higher amounts of fermentation products with antimicrobial activity, such as higher amounts of acetic acid and buchnericin, a bacteriocin (Driehuis et al., 1999; Kleinschmit and Kung, 2006; Yildirim et al., 2002).

\footnotetext{
* Corresponding author at: Departamento de Zootecnia, Universidade Estadual Paulista (UNESP), Via de acesso Prof. Paulo Donato Castellane, km5, 14884-900 Jaboticabal, SP, Brazil.

E-mail address: carlos.rabelo@ufpel.edu.br (C.H.S. Rabelo).
} 
Nevertheless, some research carried out in the last decade has also reported improvements on the dry matter intake (DMI), feed efficiency, and average daily gain (ADG) in small and large ruminants fed maize silage inoculated with L. buchneri (Basso et al., 2014; Nkosi et al., 2009; Rabelo et al., 2016a). The published literature suggests that enhanced growth performance arises from 1) positive shifts in the fermentation process and chemical composition of the silage (Rabelo et al., 2017, 2018; Winters et al., 2001), 2) improved aerobic stability of silage (Kleinschmit and Kung, 2006), and 3) higher microbial protein synthesis in the rumen (Basso et al., 2014) caused by inoculation. However, research examining the inoculation of maize silage with $L$. buchneri as a single inoculant to feed ruminants is still limited, and the ways by which this bacterium can alter growth performance are not totally understood.

Furthermore, various research has demonstrated that changing the forage:concentrate (F:C) ratio of diets is a method to positively alter growth performance and carcass traits of ruminants (e.g., Gonzaga Neto et al., 2006; Majdoub-Mathlouthi et al., 2013). In this regard, the literature shows positive results by which increasing the concentrate level in the diet can increase DMI, organic matter (OM) digestibility, and ADG (Majdoub-Mathlouthi et al., 2013; Yang et al., 2001), and alter ruminal fermentation by increasing propionate (Russell, 1998; Yang et al., 2001); but, in some cases, dry matter (DM) digestibility or feed efficiency was not altered (Rabelo et al., 2016a). Additionally, our recent study demonstrated that the inoculation of maize silage with $L$. buchneri improved the growth performance of finishing feedlot beef cattle fed the 40:60 F:C diet, but no improvements were reported in bulls fed the 60:40 F:C diet (Rabelo et al., 2016a). Therefore, it is clear there is an interaction between the silage inoculant and F:C ratio. It is expected that the effects of silage inoculation on ruminant production, if any, should be detected by feeding total mixed rations (TMR) having a higher proportion of silage instead of concentrate. However, the published literature showed inconsistent results (Rabelo et al., 2016a), and hence, the interaction between inoculation and the F:C ratio needs to be investigated further.

Thus, our study was designed to investigate the effect of feeding maize silage inoculated with L. buchneri NCIMB 40788 associated with two F:C ratios on feed intake and growth performance of lambs.

\section{Material and methods}

\subsection{Ethics statement}

Animal care and handling procedures were carried out in accordance with the Brazilian College of Animal Experimentation (COBEA) guidelines and were approved by the Ethics, Bioethics, and Animal Welfare Committee (CEBEA) of the FCAV/UNESPJaboticabal campus, Brazil (protocol no. 022704/09).

\subsection{Crop harvest and ensiling procedure}

Flint maize (Zea mays; hybrid 2B688 Hx, Dow AgroSciences, Cravinhos, SP, Brazil) was planted at a theoretical density of 66,670 seeds/ha in $0.9-\mathrm{m}$ rows in fields of Haplustox soil on 18 November 2010 , at the São Paulo State University $\left(21^{\circ} 15^{\prime} S\right.$ and $48^{\circ} 18^{\prime} \mathrm{W}$; altitude: $615 \mathrm{~m}$; Jaboticabal, SP, Brazil). Fields were fertilized with $350 \mathrm{~kg} / \mathrm{ha} \mathrm{8-28-16}$ (N-P-K) at planting. After 4- and 6-week maize growth period, fields were fertilized with $400 \mathrm{~kg} / \mathrm{ha} 20-0-20$ (N-P-K) and $400 \mathrm{~kg} / \mathrm{ha}$ urea. Glyphosate (3 L/ha; Monsanto, São José dos Campos, SP, Brazil) was applied in the field at planting and after the 3-week maize growth period. The climate at the test site is classified as "Aw" (Rolim et al., 2007) and is characterized as tropical with a wet summer and dry winter season.

On 21 February 2011 (96 d after planting), whole-crop maize was harvested in random locations throughout the field at $1 / 2$ of the kernel milk line (312 g/kg of whole-plant DM), at a stubble height of $20 \mathrm{~cm}$, using a pull-type Premium Flex forage harvester (Menta Mit, Cajuru, SP, Brazil). Forage was cut to $10 \mathrm{~mm}$; kernels were not processed. Maize forage was treated either with distilled water ( $5 \mathrm{~L} / \mathrm{t}$; untreated) or L. buchneri NCIMB 40788 at $1 \times 10^{5} \mathrm{cfu} / \mathrm{g}$ fresh forage (inoculated; Lallemand Animal Nutrition, Goiânia, GO, Brazil). The inoculant was dissolved in distilled water $(5 \mathrm{~L} / \mathrm{t})$ and sprayed onto fresh forage as the silo was filled. The application level was verified by dilution plating on Man, Rogosa, and Sharpe agar (MRS, Oxoid Ltd., Unipath, Basingstoke, UK).

Two bunker silos were filled on the same day with $60 \mathrm{t}$ of maize forage each at a packing density of approximately $530 \mathrm{~kg} / \mathrm{m}^{3} \mathrm{on}$ a fresh matter basis. To avoid possible cross contamination, the untreated forage was ensiled first, followed by the inoculated forage. To determine DM recovery, 12 bags with fresh well mixed forage $(\sim 5 \mathrm{~kg}$ ) and known DM content (Ashbell and Weinberg, 1992) were buried on the top of the silos once the silage mass reached $\sim 1 \mathrm{~m}$ in height while the silos were filled. An additional $0.5 \mathrm{~m}$ of forage was then placed on the top of each silo. Silos were sealed with a $200 \mu \mathrm{m}$ double layer silage pit cover (Electro Plastic, São Paulo, SP, Brazil). At ensiling, twelve fresh samples $(\sim 300 \mathrm{~g})$ of maize forage were collected from each silo to determine the chemical composition. Silos were stored for $70 \mathrm{~d}$ at ambient temperature $\left(23.2 \pm 1.6^{\circ} \mathrm{C}\right)$. The silage was removed from the silo face using a fork in a feedout rate of approximately $8.7 \mathrm{~cm} / \mathrm{d}$ and the implanted bags were recovered as they were encountered for measurement of DM recovery. Each bag was immediately weighed and sampled to estimate DM content of the silage. Both untreated and inoculated maize silages were used to feed lambs in this study, besides Nellore steers in a concomitant study (Rabelo et al., 2016a). Silage samples $(\sim 300 \mathrm{~g})$ were collected weekly during unloading from six locations from the feeding face of each silo (two each from the lower and upper areas and two from the center area) and bulked into a single sample on each sampling. Both forage and silage samples were stored at $-20{ }^{\circ} \mathrm{C}$ until further analysis.

\subsection{Aerobic stability}

An aerobic stability assay was carried out twice during silos unloading. Four silage samples $(\sim 3 \mathrm{~kg})$ from each bunker silo were placed in plastic buckets of 5-L capacity and kept at ambient temperature. For $5 \mathrm{~d}$, the silage and ambient temperatures were 
Table 1

Ingredient proportions and chemical composition of low (LC) and moderately high concentrate (HC) total mixed rations containing maize silage untreated (US) or inoculated with Lactobacillus buchneri NCIMB $40788^{\mathrm{a}}$ (IS).

\begin{tabular}{|c|c|c|c|c|}
\hline \multirow{2}{*}{$\begin{array}{l}\text { Forage:concentrate ratio } \\
\text { Silage }\end{array}$} & \multicolumn{2}{|l|}{ LC } & \multicolumn{2}{|l|}{$\mathrm{HC}$} \\
\hline & US & IS & US & IS \\
\hline \multicolumn{5}{|c|}{ Ingredient proportion, $\mathrm{g} / \mathrm{kg} \mathrm{DM}$} \\
\hline Maize silage & 600 & 600 & 400 & 400 \\
\hline Ground maize & 240 & 240 & 414 & 414 \\
\hline Soybean meal & 100 & 100 & 96.0 & 96.0 \\
\hline Wheat meal & 40.0 & 40.0 & 60.0 & 60.0 \\
\hline Mineral supplement ${ }^{\mathrm{c}}$ & 20.0 & 20.0 & 30.0 & 30.0 \\
\hline \multicolumn{5}{|c|}{ Chemical composition, $\mathrm{g} / \mathrm{kg} \mathrm{DM}^{\mathrm{d}}$} \\
\hline $\mathrm{DM}, \mathrm{g} / \mathrm{kg}$ as fresh basis & 517 & 524 & 630 & 634 \\
\hline $\mathrm{OM}$ & 949 & 950 & 945 & 946 \\
\hline $\mathrm{CP}$ & 139 & 141 & 142 & 143 \\
\hline $\mathrm{EE}$ & 39.0 & 38.0 & 42.2 & 41.4 \\
\hline aNDFom & 310 & 292 & 198 & 186 \\
\hline ADFom & 249 & 232 & 134 & 125 \\
\hline ME, Mcal/kg DM & 2.20 & 2.00 & 2.50 & 2.30 \\
\hline
\end{tabular}

${ }^{a}$ Whole-crop maize forage was treated at ensiling either with distilled water (5 L/t; untreated) or with $\mathrm{L}$. buchneri NCIMB 40788 at $1 \times 10^{5}$ cfu/g fresh forage (inoculated; Lallemand Animal Nutrition, Goiânia, GO, Brazil).

b Diets were composed of 1) untreated maize silage and low concentrate (400 g/kg DM; US-LC); 2) maize silage inoculated with L. buchneri and low concentrate (400 g/kg DM; IS-LC); 3) untreated maize silage and moderately high concentrate (600 g/kg DM; US-HC); and 4) maize silage inoculated with $L$. buchneri and moderately high concentrate (600 g/kg DM; IS-HC).

c Mineral supplement was composed (on a DM basis) of $65 \mathrm{~g} / \mathrm{kg} \mathrm{P,} 180 \mathrm{~g} / \mathrm{kg} \mathrm{Ca}, 70 \mathrm{~g} / \mathrm{kg} \mathrm{Na}, 100 \mathrm{~g} / \mathrm{kg} \mathrm{Cl}, 80 \mathrm{~g} / \mathrm{kg} \mathrm{Mg}, 38 \mathrm{~g} / \mathrm{kg} \mathrm{S}, 4000 \mathrm{mg} / \mathrm{kg} \mathrm{Zn}$, $100 \mathrm{mg} / \mathrm{kg} \mathrm{Cu}, 1500 \mathrm{mg} / \mathrm{kg} \mathrm{Mn}, 1100 \mathrm{mg} / \mathrm{kg} \mathrm{Fe}, 100 \mathrm{mg} / \mathrm{kg} \mathrm{Co}, 150 \mathrm{mg} / \mathrm{kg} \mathrm{I}$, and $25 \mathrm{mg} / \mathrm{kg} \mathrm{Se}$.

${ }^{\mathrm{d}} \mathrm{DM}=$ dry matter; $\mathrm{OM}=$ organic matter; $\mathrm{CP}=$ crude protein; $\mathrm{EE}=$ ether extract; aNDFom = neutral detergent fiber assayed with a heat-stable amylase and expressed exclusive of ash and protein; ADFom = acid detergent fiber expressed exclusive of residual ash; ME = metabolizable energy.

measured every half hour by dataloggers. Aerobic stability was defined as the number of hours that the silage temperature remained stable before increasing $2{ }^{\circ} \mathrm{C}$ above the ambient temperature (Moran et al., 1996).

\subsection{Animal management and feeding}

The silages described above were used to formulate four TMR daily. Diets were composed of 1) untreated maize silage and low concentrate (400 g/kg DM; US-LC); 2) maize silage inoculated with L. buchneri and low concentrate (400 g/kg DM; IS-LC); 3) untreated maize silage and moderately high concentrate $(600 \mathrm{~g} / \mathrm{kg}$ DM; US-HC); and 4) maize silage inoculated with $L$. buchneri and moderately high concentrate (600 g/kg DM; IS-HC). Diets were balanced to meet the nutrient requirements of growing lambs gaining $250 \mathrm{~g} / \mathrm{d}$ (NRC, 2007; Table 1). Feed ingredients (silage and concentrate) used to formulate TMR were sampled twice a week for DM determination and chemical analysis. The DM of ingredients measured weekly was used to adjust the proportion of ingredients in the TMR.

Twenty-eight Dorper $\times$ Santa Ines crossbred intact male, weaned, lambs $(25.7 \pm 4.3 \mathrm{~kg}$ initial body weight (BW)) were divided by weight into four groups, and then assigned $(n=7)$ to one of four diets. Lambs were housed in individual wooden pens $\left(0.5 \mathrm{~m}^{2}\right)$ with slated floors, each fitted with a feed and water container in a well-ventilated covered barn. Lambs were fed ad libitum twice daily at $0700 \mathrm{~h}$ and $1700 \mathrm{~h}$, and had free access to water. Approximately $60 \%$ of the diet was offered at $0700 \mathrm{~h}$ and the remaining $40 \%$ at $1700 \mathrm{~h}$. Orts were weighed every morning and samples of offered feed and orts were collected twice a week and stored at $-20^{\circ} \mathrm{C}$ for later analyses. Orts were used to calculate DMI daily, and their chemical composition was taken in consideration when apparent digestibility was calculated.

Lambs were adapted to the diets for $14 \mathrm{~d}$ and total feeding trial duration was $97 \mathrm{~d}$. During days 1-3 of the adaptation period, lambs were fed only maize silage. Thereafter, concentrate was included by $20 \%$ in the diet for each three subsequent days of adaptation until it reached the F:C ratios of 60:40 and 40:60, respectively. The initial and final BW was measured after a 16-h fast and ADG was calculated by subtracting the initial BW from the final BW and dividing the difference by the time in which lamb remained in the trial. Feed efficiency (feed:gain) was determined by dividing DMI by ADG.

\subsection{Cost analysis}

All costs were calculated for the period of time in which lambs were on feed; calculations were taken into account the DM recovery encountered for the untreated and inoculated silages and were not taken for individual lambs. Prices paid (U.S. dollars) were: $\$ 0.06 / \mathrm{kg}$ DM for untreated silage, $\$ 0.07 / \mathrm{kg}$ DM for inoculated silage, $\$ 0.23 / \mathrm{kg}$ DM for concentrate used in the LC diet, and $\$ 0.25 / \mathrm{kg}$ DM for concentrate used in the HC diet. Cost of gain was calculated by dividing feeding costs by total weight gained during the finishing phase. Cost of labor for daily individual feeding and costs related to feedlot structure were included in the calculations. 


\subsection{Measurement of apparent digestibility}

Apparent digestibility was calculated indirectly using indigestible neutral detergent fiber (iNDF) as a marker to estimate fecal output (Casali et al., 2008). Fecal grab samples $(\sim 30 \mathrm{~g}$ ) were collected from each lamb every $26 \mathrm{~h}$ on days $35-37$ of the feeding program (Pina et al., 2006). Samples of silage, concentrate, and orts were also collected daily during this period. Samples were composited across the 3-d period for chemical analyses and were stored at $-20{ }^{\circ} \mathrm{C}$ before analysis.

\subsection{Slaughter and carcass trait data collection}

When the lambs reached $38.5 \pm 0.86 \mathrm{~kg}$ BW, they were slaughtered by electro-narcosis anesthetization (220 V/ $0.5 \mathrm{~A})$ and subsequent bleeding by cutting their jugular veins and carotid arteries. Pre-slaughter handling was in accordance with good animal welfare practices, and slaughtering procedures followed the Sanitary and Industrial Inspection Regulation for Animal Origin Products (Brasil, 1997). After evisceration, the carcass was split into two parts and weighed to determine the hot carcass weight (HCW). All carcasses were refrigerated at $-4{ }^{\circ} \mathrm{C}$ for approximately $24 \mathrm{~h}$ and then taken from the cooling chambers and weighed again to determine the cold carcass weight (CCW). The difference between the CCW and HCW was used to calculate carcass shrink loss (CSL). Dressing percentage was calculated by dividing HCW by fasted BW and multiplying by 100 . The $12^{\text {th }}$ rib fat thickness (RFT) was measured on the left side carcasses over the loin-eye muscle using a caliper. All procedures described above for carcass trait measurements were carried out according to Silva Sobrinho and Osório (2008).

\subsection{Determination of ruminal fermentation products}

Eight ruminally cannulated Dorper $\times$ Santa Ines crossbred wethers $(50.7 \pm 4.6 \mathrm{~kg}$ initial BW), each fitted with a silicone $6.4 \mathrm{~cm}$ ruminal cannula, were used in a double $4 \times 4$ Latin Square. Each animal was housed individually in pens $(0.9 \times 2.0 \mathrm{~m})$ equipped with a feed bunk and water trough. Wethers were fed ad libitum twice daily at $0700 \mathrm{~h}$ and $1700 \mathrm{~h}$, and had free access to water; the diets used and procedures of feeding were the same as those used in the feedlot program. Orts were also weighed every morning and samples of offered feed and orts were collected twice a week and stored at $-20^{\circ} \mathrm{C}$ for later analyses.

Ruminal measurements were done over four consecutive 10-d periods without intervals between each period. Each period consisted of $9 \mathrm{~d}$ to adapt to the diets and $1 \mathrm{~d}$ for rumen fluid collection. A $50 \mathrm{ml}$ sample of ruminal fluid was collected from each wether immediately before feeding $(0 \mathrm{~h})$ and at 3, 6, 9, and $12 \mathrm{~h}$ post feeding. Ruminal fluid was squeezed through two layers of cheesecloth and the $\mathrm{pH}$ was immediately measured using a pH meter (MA522 model, Marconi Laboratory Equipment, Piracicaba, SP, Brazil). To inhibit microbial activity, $1 \mathrm{ml} \mathrm{H}_{2} \mathrm{SO}_{4}$ diluted with distilled water (1:1 v/v) was added to the ruminal fluid (50 mL) in an acid:rumen fluid ratio of $0.01: 1 \mathrm{v} / \mathrm{v}$. The resulting solution was stored at $-20^{\circ} \mathrm{C}$ for analyses of ammonia- $\mathrm{N}$ and volatile fatty acids (VFA).

\subsection{Sample preparation and chemical analyses}

To measure fermentation end products of silages, $25 \mathrm{~g}$ of fresh silage was mixed with $225 \mathrm{ml}$ of distilled water. This mixture was blended in a Phillips Walita blender (Walita, Varginha, MG, Brazil) for $1 \mathrm{~min}$ at the highest setting, and filtered through two layers of cheesecloth. The $\mathrm{pH}$ of the filtrate was measured immediately using a pH meter (model MA522, Marconi Laboratory Equipment, Piracicaba, SP, Brazil). Ammonia-N was measured by distillation (AOAC, 1996; method no. 941.04) and expressed as g/kg total N (TN). Lactic acid was determined using a colorimetric method (Barker and Summerson, 1941). Acetic acid was measured using a gas chromatograph (Shimadzu model GC2014, Shimadzu Corp., Kyoto, Japan) equipped with a capillary column (HP-INNOWax $30 \mathrm{~m} \times 0.32 \mathrm{~mm}$; Agilent Technologies, Colorado, USA) set at an initial temperature of $80^{\circ} \mathrm{C}$ for 3 min, followed by heating at a rate of $20^{\circ} \mathrm{C} / \mathrm{min}$ until a final temperature of $240{ }^{\circ} \mathrm{C}$ was reached. We followed the same procedures described above for sample preparation and analyses to measure $\mathrm{pH}$ and ammonia- $\mathrm{N}$ of the fresh forage before ensiling.

For microbial analyses, fresh silage samples $(25 \mathrm{~g})$ from each silo were collected and then homogenized in $225 \mathrm{ml}$ of autoclaved saline solution $(0.85 \% \mathrm{NaCl})$ for $1 \mathrm{~min}$. Serial dilutions from $10^{-2}$ to $10^{-9}$ were used on spread-plate potato dextrose agar (PDA) to count yeast and molds; PDA plates were incubated at $28^{\circ} \mathrm{C}$. Counts of yeasts were performed after $2 \mathrm{~d}$, and molds were counted after $5 \mathrm{~d}$. All microbiological data were $\log _{10}$-transformed to ensure normality.

Samples of forage and silage from the bunker silos, and samples of feed ingredients, orts and feces from the feedlot experiment were oven-dried at $55^{\circ} \mathrm{C}$ for $72 \mathrm{~h}$ and processed in a knife mill (Wiley mill model 4; Arthur H. Thomas Company, Philadelphia, PA) before being ground through a $1 \mathrm{~mm}$ screen and analyzed for DM $\left(105^{\circ} \mathrm{C}\right.$ for $\left.12 \mathrm{~h}\right)$ and ash $\left(500^{\circ} \mathrm{C}\right.$ for $\left.5 \mathrm{~h}\right)$ content according to methods specified by the AOAC (1996; methods no. 930.15 and 923.03, respectively). The organic matter (OM; $\mathrm{g} / \mathrm{kg}$ ) was calculated as 1000 - ash. Ether extract (EE) was determined according to the procedures described by the AOAC (1996; method no. 920.39). The total nitrogen (TN) was measured by rapid combustion using a LECO analyzer (model F528 N, LECO Corp., St. Joseph, MI, USA), and crude protein $(\mathrm{CP})$ was calculated as TN $\times 6.25$. Neutral detergent fiber (aNDFom) and acid detergent fiber (ADFom) levels were measured using the 'Ankom F57' filter bag in a fiber analyzer (ANKOM 2000, ANKOM Technologies, Macedon, NY, USA) following the procedures described by Mertens (2002) and the AOAC (1996; method no. 973.18), respectively. The aNDFom was measured using a heat-stable amylase without sodium sulphite; aNDFom was corrected for ash and protein, and ADFom was corrected for ash. Separate samples were used for ADFom analyses, and samples included residual N (ADIN). Lignin (sa) was sequentially measured after hydrolysis of the ADF residual in $72 \% \mathrm{H}_{2} \mathrm{SO}_{4}$ (Van Soest and Robertson, 1985). 
The iNDF was determined by incubating non-woven textile bags with dimension $5 \times 5 \mathrm{~cm}$ (Valente et al., 2011) containing samples of silage, concentrate, orts, and feces in triplicate in the rumens of two ruminally cannulated Nellore steers for $264 \mathrm{~h}$ (Casali et al., 2008). Samples were weighted to reach a bag surface area ratio of $20 \mathrm{mg} \mathrm{DM} / \mathrm{cm}^{2}$ (Nocek, 1988). Nellore steers were housed in individual stalls $\left(4.5 \mathrm{~m}^{2}\right)$ located in a well-ventilated, covered feedlot, each equipped with feed bunks and water bowls. Steers were fed ad libitum once day a diet composed of $60 \%$ maize silage and $40 \%$ concentrate (ground maize, soybean meal, urea, and mineral supplement), on a DM basis. Samples were then removed from the rumens of the steers and were analyzed for iNDF using an autoclave at the temperature of $110^{\circ} \mathrm{C}$ for $40 \mathrm{~min}$ (Senger et al., 2008).

Aliquots of strained ruminal fluid were thawed in a refrigerator overnight and centrifuged at $20,000 \times g$ for $30 \mathrm{~min}$ at $4{ }^{\circ} \mathrm{C}$. The supernatant was analyzed for VFA using gas chromatography according to the protocols described above for acetic acid. Ruminal ammonia-N was determined by distillation with $2 \mathrm{~N}$ KOH (Fenner, 1965).

\subsection{Calculations}

Fecal output and apparent digestibility were calculated using Eqs. (1) and (2), respectively:

Fecal output $(\mathrm{g} / \mathrm{d})=\mathrm{iNDF}$ intake $(\mathrm{g}) /$ fecal iNDF $(\%) \times 100$

Apparent digestibility $(\mathrm{g} / \mathrm{kg})=[\mathrm{DMI}(\mathrm{g})-$ fecal yield $(\mathrm{g})] / \mathrm{DMI}(\mathrm{g}) \times 100$

\subsection{Statistical analyses}

Statistical analyses of silage data were precluded because there was only one bunker silo replicate for each treatment. Feed intake, apparent digestibility, growth performance, and carcass traits were analyzed using the MIXED procedure of SAS (v. 9.4; SAS Institute Inc., Cary, NC) as a completely randomized block design $(n=7)$ under a $2 \times 2$ factorial arrangement. Diet was considered as a fixed effect and lambs and error as random effects.

Ruminal fermentation was carried out under a double $4 \times 4$ Latin Square design and analyzed as repeated measures over time using the MIXED procedure of SAS (v. 9.4; SAS Institute Inc., Cary, NC). Several covariance structures were tested and those that generated the lowest Akaike information criterion values were selected. Diet was considered a fixed effect, and wethers and period were considered as random effects.

Differences between diet means were determined using the PDIFF option of LSMEANS in SAS software (v. 9.4; SAS Institute Inc., Cary, NC), which is based on Fisher's F-protected least significant difference test. Significant differences were declared in cases where $P \leq 0.05$, and trends were considered in cases where $0.05>P \leq 0.10$.

\section{Results}

\subsection{Silage composition and fermentation characteristics}

Whole-crop maize forage had the following composition prior to ensiling, on a DM basis: $312 \mathrm{~g} \mathrm{DM} / \mathrm{kg}$ fresh weight; $52 \mathrm{~g} / \mathrm{kg}$ ash; $111 \mathrm{~g} / \mathrm{kg} \mathrm{CP} ; 16 \mathrm{~g} / \mathrm{kg} \mathrm{EE} ; 426 \mathrm{~g} / \mathrm{kg}$ aNDFom; $186 \mathrm{~g} / \mathrm{kg}$ ADFom; $9 \mathrm{~g}$ ammonia-N/kg TN; and pH of 5.40 . After $70 \mathrm{~d}$ of ensilage, inoculation lowered DM recovery and contents of aNDFom, ADFom, and lactic acid of maize silage (Table 2). Inoculation also decreased yeasts count and increased aerobic stability of maize silage by $17.2 \mathrm{~h}$.

\subsection{Apparent digestibility}

Inoculation decreased the apparent digestibility of $\mathrm{CP}$ by $6.1 \%(P=0.003 ; 626 \mathrm{vs.} 667 \mathrm{~g} / \mathrm{kg}$ for US diet $)$ and tended $(P=0.097)$ to reduce OM digestibility (704 vs. $730 \mathrm{~g} / \mathrm{kg}$ for US diet; Table 3). Moreover, as compared with LC diet, the HC diet had lower apparent digestibility of DM $(P=0.016 ; 685 \mathrm{vs.} 721 \mathrm{~g} / \mathrm{kg}), \mathrm{OM}(P=0.014 ; 697 \mathrm{vs} .737 \mathrm{~g} / \mathrm{kg})$, and CP $(P=0.001 ; 614 \mathrm{vs.} 679 \mathrm{~g} /$ $\mathrm{kg}$ ). The aNDFom digestibility was not affected by neither inoculation $(P=0.16)$, the $\mathrm{F}: \mathrm{C}$ ratio $(P=0.54)$, nor their interaction $(P=0.73)$.

\subsection{Ruminal fermentation end products}

In comparison with the LC diet, the HC diet lowered ruminal $\mathrm{pH}(P=0.022 ; 5.97$ vs. 6.13$)$ and the molar proportion of acetic acid $(P<0.001 ; 65.1$ vs. $69.0 \mathrm{mM} / 100 \mathrm{mM})$, and increased the molar proportion of propionic acid $(P=0.002 ; 24.4 \mathrm{vs.} 19.4 \mathrm{mM} /$ $100 \mathrm{mM}$; Fig. 1). Moreover, there was an interaction between inoculation and F:C ratio for ammonia-N, in which the IS-HC diet yielded the lower value $(P=0.028)$, but with no difference for the US-LC diet.

Ruminal $\mathrm{pH}$, ammonia- $\mathrm{N}$, and molar proportions of acetic acid, propionic acid, and butyric acid were all affected by the time post feeding. Lower values of ruminal pH $(P<0.001)$ were observed at 6 and $12 \mathrm{~h}$ post feeding (5.75 and 5.71, respectively; Fig. $1 \mathrm{a})$. There was a peak $(P<0.001)$ in the concentration of ammonia-N at $3 \mathrm{~h}$ post feeding $(30 \mathrm{mg} / \mathrm{dL})$, and thereafter the values dropped (Fig. 1b). Yet, there was an interaction between inoculation and time post-feeding for total VFA $(P=0.031)$, in which lambs fed the 
Table 2

Fermentation, chemical composition, and microbiological profile (mean \pm standard error of the mean) of whole-crop maize silage, either untreated or inoculated with Lactobacillus buchneri NCIMB 40788, after $70 \mathrm{~d}$ of ensilage in bunker silos $(n=12)$.

\begin{tabular}{lll}
\hline Item & Untreated $^{\mathrm{a}}$ & Inoculated $^{\mathrm{a}}$ \\
\hline $\begin{array}{l}\text { DM recovery, g/kg DM } \\
\text { Fermentation profile, g/kg DM }\end{array}$ & $905 \pm 23.8$ & $889 \pm 12.9$ \\
$\quad$ Lactic acid & $106 \pm 11.8$ & $74.7 \pm 5.31$ \\
Acetic acid & $61.4 \pm 3.43$ & $61.0 \pm 2.00$ \\
Lactic: acetic acid & $1.80 \pm 0.179$ & $1.24 \pm 0.085$ \\
pH & $3.60 \pm 0.014$ & $3.60 \pm 0.012$ \\
Ammonia-N, g/kg TN ${ }^{\mathrm{b}}$ & $50.5 \pm 0.43$ & $43.5 \pm 0.43$ \\
Chemical composition, g/kg DM & & \\
DM, g/kg as fresh basis & $315 \pm 5.40$ & $326 \pm 5.00$ \\
Ash & $35.1 \pm 0.993$ & $33.2 \pm 0.869$ \\
CP & $82.3 \pm 1.73$ & $84.3 \pm 1.81$ \\
aNDFom & $353 \pm 4.80$ & $328 \pm 5.26$ \\
iNDF, g/kg aNDFom & $388 \pm 9.80$ & $406 \pm 16.2$ \\
ADFom & $230 \pm 3.70$ & $207 \pm 3.48$ \\
Lignin & $28.8 \pm 1.71$ & $25.5 \pm 1.60$ \\
ADIN, g/kg TN & $125 \pm 4.20$ & $115 \pm 6.85$ \\
Microbiological profile, cfu/g of fresh silage & & \\
Yeasts & $4.04 \pm 0.336$ & $3.09 \pm 0.087$ \\
Molds & $2.91 \pm 0.021$ & $2.41 \pm 0.056$ \\
Aerobic stability, h & $26.1 \pm 1.67$ & $43.3 \pm 3.78$
\end{tabular}

${ }^{a}$ Whole-crop maize forage was treated at ensiling either with distilled water $(5 \mathrm{~L} / \mathrm{t}$; untreated) or with L. buchneri NCIMB 40788 at $1 \times 10^{5} \mathrm{cfu} / \mathrm{g}$ fresh forage (inoculated; Lallemand Animal Nutrition, Goiânia, GO, Brazil).

b $\mathrm{TN}=$ total N; DM = dry matter; $\mathrm{CP}=$ crude protein; aNDFom = neutral detergent fiber assayed with a heat-stable amylase and expressed exclusive of ash and protein; iNDF = indigestible neutral detergent fiber; $\mathrm{ADFom}=$ acid detergent fiber expressed exclusive of residual ash; $\mathrm{ADIN}=$ acid detergent insoluble N.

Table 3

Apparent digestibility $(\mathrm{g} / \mathrm{kg})$ in growing lambs fed low (LC) and moderately high concentrate (HC) total mixed rations containing maize silage untreated (US) or inoculated with Lactobacillus buchneri NCIMB $40788^{\text {a }}$ (IS).

\begin{tabular}{|c|c|c|c|c|c|c|c|c|}
\hline \multirow{2}{*}{$\begin{array}{l}\text { Forage:concentrate ratio }(\mathrm{F}: \mathrm{C})^{\mathrm{b}} \\
\text { Silage (S) }\end{array}$} & \multicolumn{2}{|l|}{ LC } & \multicolumn{2}{|l|}{$\mathrm{HC}$} & \multirow[t]{2}{*}{ SEM } & \multicolumn{3}{|c|}{$P$-value ${ }^{\mathrm{d}}$} \\
\hline & US & IS & US & IS & & $\mathrm{s}$ & $\mathrm{F}: \mathrm{C}$ & $\mathrm{S} \times \mathrm{F}: \mathrm{C}$ \\
\hline $\mathrm{DM}^{\mathrm{c}}$ & 734 & 708 & 690 & 680 & 1.35 & 0.183 & 0.016 & 0.562 \\
\hline $\mathrm{OM}$ & 751 & 722 & 708 & 686 & 1.45 & 0.097 & 0.014 & 0.808 \\
\hline $\mathrm{CP}$ & 707 & 650 & 626 & 601 & 1.43 & 0.003 & 0.001 & 0.200 \\
\hline aNDFom & 368 & 348 & 363 & 330 & 1.82 & 0.158 & 0.540 & 0.732 \\
\hline
\end{tabular}

${ }^{\text {a }}$ Whole-crop maize forage was treated at ensiling either with distilled water (5 L/t; untreated) or with $L$. buchneri NCIMB 40788 at $1 \times 10^{5} \mathrm{cfu} / \mathrm{g}$ fresh forage (inoculated; Lallemand Animal Nutrition, Goiânia, GO, Brazil).

b Diets were composed of 1) untreated maize silage and low concentrate (400 g/kg DM; US-LC); 2) maize silage inoculated with $L$. buchneri and low concentrate (400 g/kg DM; IS-LC); 3) untreated maize silage and moderately high concentrate (600 g/kg DM; US-HC); and 4) maize silage inoculated with $L$. buchneri and moderately high concentrate (600 g/kg DM; IS-HC).

${ }^{\mathrm{c}} \mathrm{DM}=$ dry matter; $\mathrm{OM}=$ organic matter; $\mathrm{CP}$ = crude protein; aNDFom = neutral detergent fiber assayed with a heat-stable amylase and expressed exclusive of ash and protein.

${ }^{\mathrm{d}} \mathrm{S}=$ silage; $\mathrm{F}: \mathrm{C}=$ forage:concentrate ratio; $\mathrm{S} \times \mathrm{F}: \mathrm{C}=$ interaction between silage and forage: concentrate ratio.

US diet yielded the higher concentration of total VFA at $12 \mathrm{~h}$ post feeding (69.2 vs. $59.0 \mathrm{mM}$ for the IS diet; Fig. 1c). The molar proportion of acetic acid was lower $(P<0.001)$ at 6 and $9 \mathrm{~h}$ post feeding (65.4 and $65.7 \mathrm{mM} / 100 \mathrm{mM}$, respectively; Fig. $1 \mathrm{~d})$. Otherwise, the molar proportion of propionic acid was higher $(P<0.001)$ at 6 and $9 \mathrm{~h}$ post feeding $(24.0 \mathrm{and} 23.1 \mathrm{mM} / 100 \mathrm{mM}$, respectively; Fig. 1e). The higher molar proportion of butyric acid $(P<0.001)$ was also found at 6 and 9 h post feeding $(6.87$ and $7.14 \mathrm{mM} / 100 \mathrm{mM}$, respectively; Fig. 1d).

\subsection{Feed intake, growth performance, and carcass traits}

There was an interaction between the inoculation and F:C ratio for DMI, in which lambs fed the US-LC diet had lower DMI $(P=$ 0.013) than all the other diets (Table 4). Considering a tendency for interaction between inoculation and F:C ratio, lambs fed the IS- 

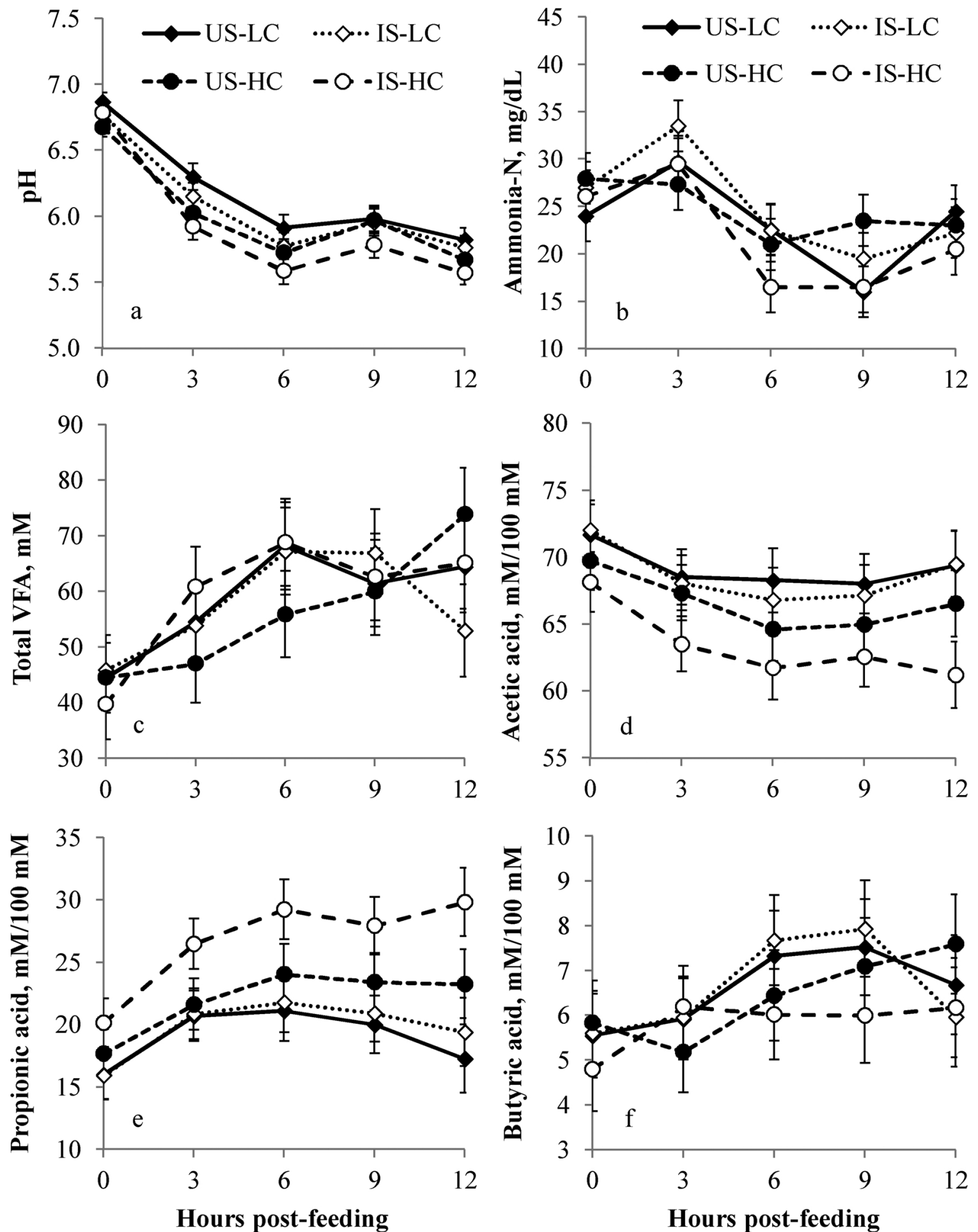

Fig. 1. Ruminal pH (a), concentrations of ammonia-N (b) and total volatile fatty acids (VFA; c), and molar proportions of acetic acid (d), propionic acid (e), and butyric acid (f) in the ruminal fluid of mature wethers fed low (LC) and moderately high concentrate (HC) total mixed rations containing maize silage untreated (US) or inoculated with Lactobacillus buchneri NCIMB 40788 (IS) at different hours post-feeding.

LC diet consumed $197 \mathrm{~g} \mathrm{OM} / \mathrm{d}$ more $(P=0.071)$ than lambs fed the US-LC diet. Lambs fed the IS-LC diet tended to have higher CP intake $(P=0.052 ;+24 \mathrm{~g} / \mathrm{d})$ than lambs fed the US-LC diet. Lambs fed the HC diet had higher CP intake $(P=0.002)$ than those fed the LC diet (187 vs. $168 \mathrm{~g} / \mathrm{d}$, respectively). 
Table 4

Feed intake, growth performance, and carcass traits of growing lambs fed low (LC) and moderately high concentrate (HC) total mixed rations containing maize silage untreated (US) or inoculated with Lactobacillus buchneri NCIMB $40788^{\mathrm{a}}$ (IS).

\begin{tabular}{|c|c|c|c|c|c|c|c|c|}
\hline \multirow{2}{*}{$\begin{array}{l}\text { Forage:concentrate ratio }(\mathrm{F}: \mathrm{C})^{\mathrm{b}} \\
\text { Silage (S) }\end{array}$} & \multicolumn{2}{|l|}{ LC } & \multicolumn{2}{|l|}{$\mathrm{HC}$} & \multirow[t]{2}{*}{ SEM } & \multicolumn{3}{|c|}{$P$-value ${ }^{\mathrm{d}}$} \\
\hline & US & IS & US & IS & & $\mathrm{S}$ & $\mathrm{F}: \mathrm{C}$ & $\mathrm{S} \times \mathrm{F}: \mathrm{C}$ \\
\hline \multicolumn{9}{|l|}{ Intake, $\mathrm{g} / \mathrm{d}$} \\
\hline $\mathrm{DM}^{\mathrm{c}}$ & $1054^{y}$ & $1258^{\mathrm{z}}$ & $1337^{\mathrm{z}}$ & $1293^{z}$ & 47.8 & 0.094 & 0.002 & 0.013 \\
\hline OM & 995 & 1192 & 1195 & 1187 & 56.2 & 0.125 & 0.112 & 0.071 \\
\hline $\mathrm{CP}$ & 156 & 180 & 186 & 188 & 6.20 & 0.025 & 0.001 & 0.052 \\
\hline aNDFom & 293 & 324 & 325 & 301 & 16.4 & 0.756 & 0.722 & 0.135 \\
\hline \multicolumn{9}{|c|}{ Growth performance and carcass traits } \\
\hline Initial BW, kg & 25.5 & 25.8 & 25.9 & 25.9 & 1.59 & 0.698 & 0.627 & 0.736 \\
\hline Final BW, kg & 38.2 & 38.9 & 38.8 & 38.3 & 0.327 & 0.734 & 0.967 & 0.179 \\
\hline Time needed to slaughter, d & 50.9 & 50.8 & 51.4 & 46.8 & 2.07 & 0.242 & 0.360 & 0.247 \\
\hline $\mathrm{ADG}, \mathrm{g} / \mathrm{d}$ & 245 & 258 & 258 & 265 & 9.33 & 0.022 & 0.030 & 0.384 \\
\hline Feed efficiency (feed:gain) & $4.37^{\mathrm{y}}$ & $4.87^{\mathrm{yz}}$ & $5.18^{\mathrm{z}}$ & $4.90^{\mathrm{yz}}$ & 0.023 & 0.579 & 0.036 & 0.048 \\
\hline HCW, kg & 17.6 & 18.7 & 18.4 & 18.7 & 0.386 & 0.125 & 0.471 & 0.260 \\
\hline Dressing percentage, $\%$ & 46.1 & 48.2 & 47.4 & 48.5 & 0.970 & 0.111 & 0.412 & 0.660 \\
\hline $\mathrm{CCW}, \mathrm{kg}$ & 17.2 & 18.2 & 17.8 & 18.0 & 0.384 & 0.162 & 0.545 & 0.327 \\
\hline CSL, \% & 2.29 & 3.08 & 2.88 & 2.95 & 0.329 & 0.082 & 0.363 & 0.115 \\
\hline RFT, mm & 2.37 & 2.66 & 3.46 & 3.61 & 0.277 & 0.321 & $<0.001$ & 0.805 \\
\hline
\end{tabular}

${ }^{\mathrm{y}-\mathrm{z}}$ Means in the same row with different superscripts differed significantly $(P<0.05)$.

${ }^{\mathrm{a}}$ Whole-crop maize forage was treated at ensiling either with distilled water (5 L/t; untreated) or with L. buchneri NCIMB 40788 at $1 \times 10^{5}$ cfu/g fresh forage (inoculated; Lallemand Animal Nutrition, Goiânia, GO, Brazil).

b Diets were composed of 1) untreated maize silage and low concentrate (400 g/kg DM; US-LC); 2) maize silage inoculated with L. buchneri and low concentrate (400 g/kg DM; IS-LC); 3) untreated maize silage and moderately high concentrate (600 g/kg DM; US-HC); and 4) maize silage inoculated with $L$. buchneri and moderately high concentrate $(600 \mathrm{~g} / \mathrm{kg}$ DM; IS-HC).

${ }^{\mathrm{c}} \mathrm{DM}=$ dry matter; $\mathrm{OM}=$ organic matter; $\mathrm{CP}=$ crude protein; aNDFom = neutral detergent fiber assayed with a heat-stable amylase and expressed exclusive of ash and protein; BW = body weight; ADG = average daily gain; HCW = hot carcass weight; CCW = cold carcass weight; $\mathrm{CSL}=$ carcass shrink losses; RFT $=$ rib fat thickness.

${ }^{\mathrm{d}} \mathrm{S}=$ silage; $\mathrm{F}: \mathrm{C}=$ forage:concentrate ratio; $\mathrm{S} \times \mathrm{F}: \mathrm{C}=$ interaction between silage and forage:concentrate ratio.

There was no interaction between inoculation and F:C ratio for ADG $(P=0.38)$, but inoculation increased the ADG of lambs $(P=0.022)$ mostly when they were fed the LC diet $(+13 \mathrm{~g} / \mathrm{d}$ in comparison with the US-LC diet) than that observed for the HC diet $(+7 \mathrm{~g} / \mathrm{d}$ in comparison with the US-HC diet; Table 4). Additionally, lambs fed the HC diet had higher ADG $(P=0.030)$ than those fed the LC diet (262 vs. $252 \mathrm{~g} / \mathrm{d}$ ). There was an interaction between inoculation and F:C ratio for feed efficiency, in which lambs fed the US-HC diet had lower efficiency $(P=0.048)$ than those fed the US-LC diet. Even though there was no effect of inoculation for the time needed to slaughter $(P=0.24)$, lambs fed the IS-HC diet numerically needed less time to be slaughtered (46.8 d). Neither inoculation $(P=0.11), \mathrm{F}: \mathrm{C}$ ratio $(P=0.41)$, nor their interaction $(P=0.66)$ affected dressing percentage. Finally, we reported higher RFT in lambs fed the HC diet in comparison with the LC diet $(P=0.001 ; 3.54 \mathrm{vs} .2 .52 \mathrm{~mm})$.

\subsection{Cost analysis}

Feed costs were higher in the HC diet compared with the LC diet (Table 5). Inoculation increased total costs per head (per day and

Table 5

Feed cost analysis (US\$) regarding the growing lambs production by feeding low (LC) and moderately high concentrate (HC) total mixed rations containing maize silage untreated (US) or inoculated with Lactobacillus buchneri NCIMB $40788^{\text {a }}$ (IS).

\begin{tabular}{lllll}
\hline Forage:concentrate ratio & \multicolumn{2}{l}{ LC } & & HC \\
\cline { 3 - 5 } Silage & US & IS & US \\
\hline Feeding cost/kg of feed (as-is DM basis) & & 0.16 & 0.16 \\
Total cost per animal/d & 0.14 & 0.14 & 0.21 & 0.16 \\
Total delivered cost/animal & 7.51 & 8.81 & 10.80 & 0.21 \\
Feed cost/kg of weight gain & 0.58 & 0.67 & 0.83 \\
\hline
\end{tabular}

${ }^{a}$ Whole-crop maize forage was treated at ensiling either with distilled water (5 L/t; untreated) or with L. buchneri NCIMB 40788 at $1 \times 10^{5}$ cfu/g fresh forage (inoculated; Lallemand Animal Nutrition, Goiânia, GO, Brazil).

b Diets were composed of 1) untreated maize silage and low concentrate (400 g/kg DM; US-LC); 2) maize silage inoculated with L. buchneri and low concentrate (400 g/kg DM; IS-LC); 3) untreated maize silage and moderately high concentrate (600 g/kg DM; US-HC); and 4) maize silage inoculated with $L$. buchneri and moderately high concentrate $(600 \mathrm{~g} / \mathrm{kg}$ DM; IS-HC).

${ }^{\mathrm{c}}$ Costs were obtained in Brazilian real and then converted to US dollar in a ratio of $\mathrm{R} \$ 3.80$ to US\$1.00. 
for total feedlot period) when lambs were fed the LC diet, but the highest costs were observed by feeding the HC diet. Likewise, inoculation increased the cost per kg of weight gain by $15.5 \%$ in lambs fed the LC diet, but the highest costs were found by feeding the HC diet.

\section{Discussion}

In the current study, the number of farm-scale silos used per treatment $(n=1)$ and sampling procedure carried out during unloading prevented a meaningful statistical analysis of fermentation and chemical composition of maize silage (Udén and Robinson, 2015). However, a discussion about the most obvious silage variables affected by bacterial inoculation is needed because ultimately they affected the growth performance of lambs. The chemical composition of maize silage was typical of those produced under tropical areas (Arriola et al., 2011a; Rabelo et al., 2018; Rodrigues et al., 2015). Inoculation of maize silage with L. buchneri reduced lactic acid concentration and DM recovery, which is in agreement with the results of previous studies (Driehuis et al., 1999; Kleinschmit and Kung, 2006). Under anaerobic conditions, L. buchneri was found to convert lactic acid to acetic acid and 1,2propanodiol (Oude Elferink et al., 2001). Beyond this ability, it is well-established that obligate heterofermentative LAB may decrease DM recovery due to production of $\mathrm{CO}_{2}$ from water-soluble carbohydrates utilization during silage fermentation (Kleinschmit and Kung, 2006; Pahlow et al., 2003). Despite the increased lactic acid concentration in the untreated silage, inoculation did not affect $\mathrm{pH}$. We do not have a clear explanation for such result, once silage $\mathrm{pH}$ can be affected by factors other than lactic acid concentration (Kung et al., 2018); for instance, DM content and bacterial community over the ensiled crop might affect production and utilization of organic acids, and ultimately, affecting silage pH (McDonald et al., 1991). Anyway, both untreated and inoculated silages had low $\mathrm{pH}$, which reflected in a suitable fermentation due to restriction of the growth of undesirable microorganisms like clostridia. Nevertheless, surprisingly acetic acid concentration was not altered following inoculation, which is a typical response reported in $L$. buchneri-treated silages. The cause for such result is likely related with the low packing density of the silages used in our experiment (approximately $530 \mathrm{~kg} / \mathrm{m}^{3}$ on a fresh matter basis). The low packing density favors the $\mathrm{O}_{2}$ movement into silage leading a more rapid or more extensive, or both, growth of spoilage microorganisms, such as acetic acid bacteria, over maize silage (Muck et al., 2003; Pahlow et al., 2003). Acetic acid bacteria are recognized for its ability to oxidize acetic acid to $\mathrm{CO}_{2}$ and water while maize silage is liable to aerobic deterioration (Pahlow et al., 2003). Thus, the higher reentrance of air into the inoculated silage after the silo was opened likely led to the higher acetic acid oxidation by acetic acid bacteria, which slightly lowered acetic acid concentration as compared with the untreated silage. However, till date, there is no research investigating whether there is any interaction between acetic acid bacteria and silages containing increased acetic acid concentration; thus, further investigations are needed. Our findings are in agreement with previous studies, which reported similar or even higher concentration of lactic acid with no changes in acetic acid in maize silages treated with L. buchneri (Arriola et al., 2011a, 2011b). Inoculation yielded maize silages with lower counts of yeasts and higher aerobic stability. Since acetic acid was similar between silages, these results likely arise from the lowered lactic: acetic acid ratio in the inoculated silage. In the presence of air, yeasts are able to metabolize lactic acid, but not volatile fatty acids, which have antifungal properties (McDonald et al., 1991; Pahlow et al., 2003); metabolism of yeasts may reflect in silage heating and then, aerobic stability is reduced (Wilkinson and Davies, 2013). Moreover, L. buchneri may also produce other antimicrobial substances such as Buchnericin LB, a bacteriocin, which may be responsible for improved aerobic stability (Yildirim, 2001). Improved aerobic stability was found in maize silage treated with L. buchneri, even with no changes in acetic acid (Arriola et al., 2011a).

Furthermore, it is well-established that ensiling process cause remarkable changes in the nutritive value of the ensiled forage (McDonald et al., 1991). In the current study, ensiling maize lowered aNDFom content ( $-85.5 \mathrm{~g} / \mathrm{kg}$ DM) while increased ADFom $(+32.5 \mathrm{~g} / \mathrm{kg} \mathrm{DM})$. Likely this response arises from the hemicellulose breakdown caused by hydrolysis due to production of organic acids during silage fermentation (McDonald et al., 1991). Decreased aNDFom accompanied of increased ADFom has been reported in well-preserved silages (Basso et al., 2014; Comino et al., 2014; Nkosi et al., 2009).

Inoculation of whole-crop maize silage with L. buchneri increased DMI in lambs fed the LC diet, but not for those fed the HC diet. This result may be associated with the lower NDF content in the inoculated silage as compared with the untreated one. The reasons for the reduction in aNDFom content following inoculation with L. buchneri are unclear, because the strain used in the present study has no ferulic acid esterase activity. However, inoculation with $L$. buchneri holding no enzyme activity yielded maize silages with lower NDF content in previous studies (Arriola et al., 2011a; Nkosi et al., 2011). A reduction in the NDF content should reduce ruminal bulk fill and allow a higher intake of diets rich in forage (Addah et al., 2012), as reported in the current study. Conversely, the lack of effects from inoculation on DMI in lambs fed the HC diet probably may be attributed to the increased concentrate level in the diet. Increasing the concentrate level in the diet typically increases readily digestible carbohydrates, and hence it is unlikely that a small decrease in the NDF content of silage following inoculation would have a measurable impact on DMI in these conditions. The enhanced DMI caused by inoculation in lambs fed the LC diet is in agreement with the higher DMI reported in South African Dorper lambs and mutton Merino rams fed diets of whole-crop maize silage inoculated with L. buchneri (Nkosi et al., 2009, 2011). Moreover, the results of the current study agree with our survey about the use of silage inoculants in Brazil, in which inoculation of maize silage increased the DMI of sheep by $57 \%$ (on average $+140 \mathrm{~g} \mathrm{DM} / \mathrm{d}$ ) in the studies investigated (Rabelo et al., 2016b).

Despite the increased intakes of DM and CP in lambs fed the IS-LC diet, inoculation of maize silage consistently decreased CP digestibility in lambs fed both the LC and HC diets, and tended to reduce OM digestibility. A previous study reported a negative relationship between the amount of feed consumed and OM digestibility in sheep (Doreau et al., 2003). Although the passage rate and ruminal retention time of particles in the rumen were not measured in this study, they are a plausible explanation for the reduced digestibility in the IS diet, particularly when it was associated with the LC diet. In cases where there is an elevated consumption, the impaired digestibility may be linked to the lower ruminal retention time of particles in the rumen and increased passage rate (Doreau 
et al., 2003). This result agrees with our previous study, in which Nellore steers fed diets composed of maize silage inoculated with $L$. buchneri had lower DM and NDF digestibility (Rabelo et al., 2016a). However, the slight reduction in the CP digestibility caused by inoculation in lambs fed HC diets remains unclear and needs to be investigated further. Furthermore, lambs fed the HC diet consistently had lower apparent digestibility of DM, OM, and CP. This response is possibly associated with a rapid digesta passage rate through the gastrointestinal tract of sheep fed a HC diet caused by the higher feed intake, negatively affecting the digestibility (Doreau et al., 2003). Nevertheless, data of feed digestibility should be interpreted with caution because we did not measure the passage rate and ruminal retention time of particles in the rumen, and apparent digestibility was measured indirectly, although the methodologies have been validated previously (Casali et al., 2008; Pina et al., 2006).

Lambs fed the HC diet had lower ruminal $\mathrm{pH}$ and molar proportion of acetic acid, whereas the molar proportion of propionic acid was higher; this response was expected because the HC diet might contain higher amount of readily digestible carbohydrates. Furthermore, decreasing forage-to-concentrate diets often decrease time spent chewing and salivation, and ruminal $\mathrm{pH}$ drops because buffering is reduced (Davis et al., 1964; Maekawa et al., 2002; Owens et al., 1998). Propionate is increased by the higher activity of starch-fermenting bacteria (Russell, 1998), and acetate is reduced (Yang et al., 2001).

Inoculation did not affect the concentration of total VFA, or the molar proportion of VFA. Alterations in ruminal fermentation following inoculation with L. buchneri is difficult to envision, because previous research reported 1) alterations in molar proportion of acetate and propionate with no effect on total VFA (Rabelo et al., 2016a, 2018), 2) no effect on molar proportion and total VFA (Basso et al., 2014), and 3) reduction on total VFA with no effect on VFA molar proportion (Mohammadzadeh et al., 2012). In this regard, our recent study (Rabelo et al., 2018) suggested that shifts in the in vivo ruminal fermentation caused by inoculation with $L$. buchneri are most linked with alterations in the chemical composition of silages than by the direct action of this bacterium inside the rumen. Although inoculation altered silage composition (e.g., lowered lactic acid and aNDFom) in the current study, these alterations were not enough to lead to shifts in molar proportion and total VFA. However, inoculation lowered ruminal ammonia-N in wethers fed the $\mathrm{HC}$ diet, but not the LC diet. High-concentrate diets typically have lower concentrations of ruminal ammonia- $\mathrm{N}$ because the low pH might reduce the deamination rate of the bacteria (Lana et al., 1998). Furthermore, inoculation of maize silage with $L$. buchneri could increase soluble protein of silage by degrading hydrophobic zein proteins (Hoffman et al., 2011), since this bacterium was found to have proteolytic activity (Heinl and Grabherr, 2017). Hence, ruminal protein degradation could be affected as well (Charmley, 2001). Nevertheless, inoculation with $L$. buchneri in this study yielded minimal differences in the concentrations of ammonia-N and acid detergent insoluble $\mathrm{N}$ of maize silages, and therefore, it is unlikely that these factors had a high impact on ruminal ammonia accumulation. Since ruminal ammonia accumulation results from a complex interaction between the $\mathrm{F}$ : $\mathrm{C}$ ratio, dietary protein solubility, and energy content, ruminal fermentation, microbial community and growth, and host (Charmley, 2001; Clark et al., 1992; Lana et al., 1998), it is difficult to explain why inoculation reduced ammonia-N in lambs fed the HC diet, but not in those fed the LC diet. Furthermore, caution is needed for interpretation of ruminal fermentation, once the data were measured in mature wethers, which were 2-fold the weight of growing lambs used in the feeding trial. It is known that feed intake and energy requirements of ruminants are altered with aging due to changes in body composition (NRC, 2007; Owens et al., 1993), and thus, feed digestibility and ruminal fermentation might be affected.

Inoculation of maize silage with $L$. buchneri increased the ADG of lambs, especially when they consumed the $\mathrm{LC}$ diet $(+13 \mathrm{~g} / \mathrm{d})$. This result can be attributed to the higher DMI observed in lambs fed the IS-LC diet. The slight increase in the ADG ( $+7 \mathrm{~g} / \mathrm{d}$ ) of lambs fed the IS-HC diet than that of the US-HC diet was not expected, owing to the lack of differences in DMI and because of the reduced OM digestibility; and therefore, the causes for this are unknown. Furthermore, increasing the concentrate level in the diet resulted in increased ADG of lambs, a response possibly related to the higher DMI observed in lambs fed the HC diet. Feed efficiency was altered only in lambs fed a US diet, and increasing concentrate levels in the diet reduced the feed efficiency, a response probably attributed to the decreased feed digestibility. Even with no statistical differences, lambs fed the US-LC, IS-LC, and US-HC diets needed 4.1, 4.0, and $4.6 \mathrm{~d}$ more than those fed the IS-HC diet to be slaughtered. Commercially, this result can represent increased profitability by reducing costs associated with feeding. In our previous study (Rabelo et al., 2016a), bulls fed the IS-HC diet had higher ADG than that of all of other treatments. However, despite the positive effect of inoculation on ADG of lambs, mainly in those fed the LC diet, the US-LC diet was found to have lower costs regarding feeding per kilogram of weight gain. This response arises from the improved feed efficiency observed in lambs fed the US-LC diet. Since the rate for adopting of a new technology is subject to its profitability (Ben Salem and Smith, 2008), it is necessary caution to use bacterial inoculants in order to improve silage quality and animal performance. In literature, L. buchneri was found to increase the aerobic stability of corn silage ( $>475 \mathrm{~h}$; Kleinschmit and Kung, 2006) and to decrease spoiled silage removed daily from silos ( $<44 \%$; Queiroz et al., 2012); in such conditions, it is likely that the feeding costs could be recovered by improving silage preservation. Nonetheless, our findings showed that small improvements in growth performance of lambs following inoculation with $L$. buchneri are unlikely to increase profitability when silage DM recovery is lowered and aerobic stability does not increase substantially.

Carcass measurements of lambs were only affected minimally by either inoculation or F:C ratio, but lambs fed an HC diet had higher RFT values than those fed LC diets. This result arises from the higher DMI observed for lambs fed the HC diet, and also because high-concentrate diets often have higher energy contents than low-concentrate diets; therefore, this energy is used for abdominal and subcutaneous fat deposition (Pethick et al., 2004). Our findings are in agreement with previous studies, in which increased values of RFT were reported in lambs fed high-concentrate based diets in comparison with those fed low-concentrate based diets (Gonzaga Neto et al., 2006; Majdoub-Mathlouthi et al., 2013).

Overall, the results of the current study revealed that inoculation of maize silage with L. buchneri may improve growth performance of lambs, but this response is highly dependent of the F:C ratio and does not mean increased profitability according to our experimental conditions; this finding is in accordance with our previous study with bulls (Rabelo et al., 2016a). Furthermore, 
enhanced animal performance following silage inoculation has been reported in literature (Oliveira et al., 2017; Rabelo et al., 2016b; Weinberg and Muck, 1996). Previous studies suggested that the causes for the increased growth performance of animals consuming inoculated silage might be associated with 1) improved silage fermentation and composition (Rabelo et al., 2018; Winters et al., 2001), 2) increased aerobic stability of silage (Kleinschmit and Kung, 2006), 3) increased microbial protein synthesis in the rumen (Basso et al., 2014), and 4) a potential probiotic effect caused by bacteria contained in silage inoculants, which may change ruminal fermentation in order to improve feed efficiency (Weinberg and Muck, 1996; Weinberg et al., 2003, 2007). However, it is worth mentioning that the causes for improved animal performance following silage inoculation in most cases is unclear and further studies are needed to elucidate how silage inoculants improve the animal performance.

\section{Conclusions}

Inoculation of maize silage with $L$. buchneri increased the feed intake of lambs only when they were fed the LC diet. As a consequence, inoculation increased ADG mostly in lambs fed the LC than those fed the HC diet. In contrast, inoculation consistently decreased feed digestibility. Regarding the F:C ratio, increasing concentrate levels in the diet increased feed intake and ADG, whereas reduced feed digestibility. In summary, the effects of silage inoculation with $L$. buchneri on lamb production were detected by feeding TMR with a higher proportion of silage; however, the enhanced growth performance was not accompanied of reduced feeding costs.

\section{Conflict of interest}

The authors declare there is no conflict of interest.

\section{Acknowledgments}

The authors wish to thank the "São Paulo Research Foundation" (FAPESP grants \#2009/16458-0 and \#2012/00412-4) for its financial support.

\section{References}

Addah, W., Baah, J., Okine, E.K., McAllister, T.A., 2012. A third-generation esterase inoculant alters fermentation pattern and improves aerobic stability of barley silage and the efficiency of body weight gain of growing feedlot cattle. J. Anim. Sci. 90, 1541-1552.

AOAC, 1996. Official Methods of Analysis, 16 ed. AOAC, Washington DC, USA.

Arriola, K.G., Kim, S.C., Staples, C.R., Adesogan, A.T., 2011a. Effect of applying bacterial inoculants containing different types of bacteria to corn silage on the performance of dairy cattle. J. Dairy Sci. 94, 3973-3979.

Arriola, K.G., Kim, S.C., Adesogan, A.T., 2011b. Effect of applying inoculants with heterolactic or homolactic and heterolactic bacteria on the fermentation and quality of corn silage. J. Dairy Sci. 94, 1511-1516.

Ashbell, G., Weinberg, Z.G., 1992. Top silage losses in horizontal silos. Can. Agric. Engineer. 34, 171-175.

Barker, S.B., Summerson, W.H., 1941. The colorimetric determination of lactic acid in biological material. J. Biol. Chem. 138, $535-554$.

Basso, F.C., Adesogan, A.T., Lara, E.C., Rabelo, C.H.S., Berchielli, T.T., Teixeira, I.A.M.A., Siqueira, G.R., Reis, R.A., 2014. Effects of feeding corn silage inoculated with microbial additives on the ruminal fermentation, microbial protein yield, and growth performance of lambs. J. Anim. Sci. 92, 5640-5650.

Ben Salem, H., Smith, T., 2008. Feeding strategies to increase small ruminant production in dry environments. Small Rumin. Res. 77, 174-194.

Brasil, 1997. Ministério da agricultura. Pecuária e Abastecimento. Regulamento da Inspeção Industrial e Sanitária de Produtos de Origem (Animal Food of Animal Origin Sanitary and Industry Inspection). Ministério da Agricultura, Pecuária e Abastecimento, Brasília.

Casali, A.O., Detmann, E., Valadares Filho, S.C., Pereira, J.C., Henriques, L.T., Freitas, S.G., Paulino, M.F., 2008. Influence of incubation time and particles size on indigestible compounds contents in cattle feeds and feces obtained by in situ procedures. Rev. Bras. Zootec. 37, $335-342$.

Charmley, E., 2001. Towards improved silage quality - a review. Can. J. Anim. Sci. 1, 157-168.

Clark, J.H., Klusmeyer, T.H., Cameron, M.R., 1992. Microbial protein synthesis and flows of nitrogen fractions to the duodenum of dairy cows. J. Dairy Sci. 75, 2304-2323.

Comino, L., Tabacco, E., Righi, F., Revello-Chion, A., Quarantelli, A., Borreani, G., 2014. Effects of an inoculant containing a Lactobacillus buchneri that produces ferulate-esterase on fermentation products, aerobic stability, and fibre digestibility of maize silage harvested at different stages of maturity. Anim. Feed Sci. Technol. 198, 94-106.

Davis, C.L., Brown, R.E., Beitz, D.C., 1964. Effect of feeding high-grain restricted-roughage rations with and without bicarbonates on the fat content of milk produced and proportions of volatile fatty acids in the rumen. J. Dairy Sci. 47, 1217-1219.

Doreau, M., Michalet-Doreau, B., Grimaud, P., Atti, N., Nozière, P., 2003. Review: consequences of underfeeding on digestion and absorption in sheep. Small Rumin. Res. 49, 289-301.

Driehuis, F., Oude Elferink, S.J.W.H., Spoelstra, S.F., 1999. Anaerobic lactic acid degradation during ensilage of whole crop maize inoculated with Lactobacillus buchneri inhibits yeast growth and improves aerobic stability. J. Appl. Microbiol. 87, 583-594.

Fenner, H., 1965. Method for determining total volatile bases in rumen fluid by stem distillation. J. Dairy Sci. 48, $249-251$.

Gonzaga Neto, S., Silva Sobrinho, A.G., Zeola, N.M.B.L., Marques, C.A.T., Silva, A.M.A., Pereira Filho, J.M., Ferreira, Â.C.D., 2006. Quantitative characteristics of the carcass of Morada Nova lambs fed different dietary ratios of forage and concentrate. Rev. Bras. Zootec. 35, 1487-1495.

Heinl, S., Grabherr, R., 2017. Systems biology of robustness and flexibility: Lactobacillus buchneri - a show case. J. Biotechnol. 257, 61-69.

Hoffman, P.C., Esser, N.M., Shaver, R.D., Coblentz, W.K., Scott, M.P., Bodnar, A.L., Schmidt, R.J., Charley, R.C., 2011. Influence of ensiling time and inoculation on alteration of the starch-protein matrix in high-moisture corn. J. Dairy Sci. 94, 2465-2474.

Kleinschmit, D.H., Kung, L.Jr., 2006. A meta-analysis of the effects of Lactobacillus buchneri on the fermentation and aerobic stability of corn and grass and small-grain silages. J. Dairy Sci. 89, 4005-4013.

Kung Jr., L., Shaver, R.D., Grant, R.J., Schmidt, R.J., 2018. Silage review: interpretation of chemical, microbial, and organoleptic components of silages. J. Dairy Sci. 101, 4020-4033.

Lana, R.P., Russell, J.B., Van Amburgh, M.E., 1998. The role of pH in regulating ruminal methane and ammonia production. J. Anim. Sci. 76, $2190-2196$.

Maekawa, M., Beauchemin, K.A., Christensen, D.A., 2002. Effect of concentrate level and feeding management on chewing activities, saliva production, and ruminal $\mathrm{pH}$ of lactating dairy cows. J. Dairy Sci. 85, 1165-1175.

Majdoub-Mathlouthi, L., Saïd, B., Say, A., Kraiem, K., 2013. Effect of concentrate level and slaughter body weight on growth performances, carcass traits and meat quality of Barbarine lambs fed oat hay based diet. Meat Sci. 93, 557-563. 
McDonald, P., Henderson, A.R., Heron, S.J.E., 1991. The Biochemistry of Silage, 2nd ed. Chalcombe Publications, Abersytwyth, UK.

Mertens, D.R., 2002. Gravimetric determination of amylase-treated neutral detergent fiber in feeds with refluxing in beakers or crucibles: collaborative study. J. AOAC Int. 85, 1217-1240.

Mohammadzadeh, H., Khorvash, M., Ghorbani, G.R., Yang, W.Z., 2012. Frosted corn silage with or without bacterial inoculants in dairy cattle ration. J. Drug Deliv. Sci. Technol. 145, 153-159.

Moran, J.P., Weinberg, Z.G., Ashbell, G., Hen, Y., Owen, T.R., 1996. A comparison of two methods for the evaluation of the aerobic stability of whole crop wheat silage. Proc. 11th Int. Silage Conf., Univ. of Wales 162-163.

Muck, R.E., Moser, L.E., Pitt, R.E., 2003. Postharvest factors affecting ensiling. In: Buxton, D.R., Muck, R.E., Harrison, J.H. (Eds.), Silage Science and Technology. American Society of Agronomy, Madison, WI, pp. 251-304.

Nkosi, B.D., Meeske, R., Palic, D., Langa, T., Leeuwa, K.J., Groenewald, I.B., 2009. Effects of ensiling whole crop maize with bacterial inoculants on the fermentation, aerobic stability, and growth performance of lambs. Anim. Feed Sci. Technol. 154, 193-203.

Nkosi, B.D., Meeske, R., Langa, T., Thomas, R.S., 2011. Effects of bacterial silage inoculants on whole-crop maize silage fermentation and silage digestibility in rams. South Afr. J. Anim. Sci. 41, 350-359.

Nocek, J.E., 1988. In situ and other methods to estimate ruminal protein and energy digestibility: a review. J. Dairy Sci. 71, 2051-2069.

NRC, 2007. Nutrient Requirements of Small Ruminants: Sheep, Goats, Cervids, and New World Camelids. Natl. Acad. Press, Washington, DC, USA.

Oliveira, A.S., Weinberg, Z.G., Ogunade, I.M., Cervantes, A.A.P., Arriola, K.G., Jiang, Y., Kim, D., Li, X., Gonçalves, M.C.M., Vyas, D., Adesogan, A.T., 2017. Metaanalysis of effects of inoculation with homofermentative and facultative heterofermentative lactic acid bacteria on silage fermentation, aerobic stability, and the performance of dairy cows. J. Dairy Sci. 100, 4587-4603.

Oude Elferink, S.J.W.H., Krooneman, J., Gottschal, J.C., Spoelstra, S.F., Faber, F., Driehuis, F., 2001. Anaerobic conversion of lactic acid to acetic acid and 1,2 propanodiol by Lactobacillus buchneri. Appl. Environ. Microbiol. 67, 125-132.

Owens, F.N., Dubeski, P., Hanson, C.F., 1993. Factors that alter the growth and development of ruminants. J. Anim. Sci. 71, $3138-3150$.

Owens, F.N., Secrist, D.S., Hill, W.J., Gill, D.R., 1998. Acidosis in cattle: a review. J. Anim. Sci. 76, 275-286.

Pahlow, G., Muck, R.E., Driehuis, F., Oude-Elferink, S.J.W.H., Spoelstra, S.F., 2003. Microbiology of ensiling. In: Buxton, D.R., Muck, R.E., Harrison, J.H. (Eds.), Silage Science and Technology. American Society of Agronomy, Madison, WI, pp. 31-93.

Pethick, D.W., Harper, G.S., Oddy, V.H., 2004. Growth, development and nutritional manipulation of marbling in cattle: a review. Aust. J. Exp. Agric. 44, 705-715.

Pina, D.S., Valadares Filho, S.C., Detmann, E., Valadares, R.F.D., Campos, J.M.S., Moraes, K.A.K., Oliveira, A.S., Paixão, M.L., 2006. Comparison of internal markers and extent of total fecal collection to estimate nutrient digestibility and energy value of feeds on dairy cows fed different protein sources. Rev. Bras. Zootec. 35 , 2461-2468.

Queiroz, O.C.M., Adesogan, A.T., Arriola, K.G., Queiroz, M.F.S., 2012. Effect of a dual-purpose inoculant on the quality and nutrient losses from corn silage produced in farm-scale silos. J. Dairy Sci. 95, 3354-3362.

Rabelo, C.H.S., Basso, F.C., McAllister, T.A., Lage, J.F., Gonçalves, G.S., Lara, E.C., Oliveira, A.A., Berchielli, T.T., Reis, R.A., 2016a. Influence of Lactobacillus buchneri as silage additive and forage:concentrate ratio on the growth performance, fatty acid profile in longissimus muscle, and meat quality of beef cattle. Can. J. Anim. Sci. 96, 550-562.

Rabelo, C.H.S., Mari, L.J., Reis, R.A., 2016b. Survey about the use of bacterial inoculants in Brazil: effects on silage quality and animal performance. In: Silva, T., Santos, E.M. (Eds.), Advances in Silage Production and Utilization. InTech, Rijeka, Croatia, pp. 3-37.

Rabelo, C.H.S., Basso, F.C., Lara, E.C., Jorge, L.G.O., Härter, C.J., Mari, L.J., Reis, R.A., 2017. Effects of Lactobacillus buchneri as a silage inoculant or probiotic on in vitro organic matter digestibility, gas production, and volatile fatty acids of low dry matter whole-crop maize silage. Grass Forage Sci. 72 , $534-544$.

Rabelo, C.H.S., Basso, F.C., Lara, E.C., Jorge, L.G.O., Härter, C.J., Mesquita, L.G., Silva, L.F.P., Reis, R.A., 2018. Effects of Lactobacillus buchneri as a silage inoculant and as a probiotic on feed intake, apparent digestibility and ruminal fermentation and microbiology in wethers fed low-dry-matter whole-crop maize silage. Grass Forage Sci. 73, 67-77.

Rodrigues, P.H.M., Pinedo, L.A., Marino, C.T., Meyer, P.M., Borgatti, L.M.O., Franco, F.M.J., 2015. Effects of microbial inoculants and by-product from amino acids production on fermentation, chemical composition and aerobic stability of corn silage. Arch. Zootec. 64, $131-138$.

Rolim, G.S., Camargo, M.B.P., Lania, D.G., Moraes, J.F.L., 2007. Climatic classification of Köppen and Thornthwaite systems and their applicability in the determination of agroclimatic zoning for the state of São Paulo, Brazil. Bragantia 66, 711-720.

Russell, J.B., 1998. The importance of pH in the regulation of ruminal acetate to propionate ratio and methane production in vitro. J. Dairy Sci. 81, 3222-3230.

Senger, C.C.D., Kozloski, G.V., Sancez, L.M.B., Mesquita, F.R., Alves, T.P., Castagnino, D.S., 2008. Evaluation of autoclave procedures for fibre analysis in forage and concentrate feedstuffs. Anim. Feed Sci. Technol. 146, 169-174.

Silva Sobrinho, A.G., Osório, J.C.S., 2008. Aspectos quantitativos da produção de carne ovina. In: Silva Sobrinho, A.G., Sañudo, C., Osório, J.C.S., Arribas, M.M.C., Osório, M.T.M. (Eds.), Produção de Carne Ovina. FUNEP, Jaboticabal, SP, Brazil, pp. 1-68.

Udén, P., Robinson, P.H., 2015. Design and statistical issues in silage experiments. In: Daniel, J.L.P., Morais, G., Junges, D., Nussio, L.G. (Eds.), Proceedings of the XVII International Silage Conference. Piracicaba, SP, Brazil: ESALQ, pp. 166-179.

Valente, T.N.P., Detmann, E., Valadares Filho, S.C., Cunha, M., Queiroz, A.C., Sampaio, C.B., 2011. In situ estimation of indigestible compounds concentrations in cattle feed and feces using bags made from different textiles. R. Bras. Zootec. 40, 666-675.

Van Soest, P.J., Robertson, J.B., 1985. Analysis of Forages and Fibrous Foods. Cornell University, Ithaca.

Weinberg, Z.G., Muck, R.E., 1996. New trends and opportunities in the development and use of inoculants for silage. FEMS Microbiol. Rev. 19, 53-68.

Weinberg, Z.G., Muck, R.E., Weimer, P.J., 2003. The survival of silage inoculant lactic acid bacteria in rumen fluid. J. Appl. Microbiol. 94, 1066-1071.

Weinberg, Z.G., Shatz, O., Chen, Y., Yosef, E., Nikbahat, M., Ben-Ghedalia, D., Miron, J., 2007. Effect of lactic acid bacteria inoculants on in vitro digestibility of wheat and corn silages. J. Dairy Sci. 90, 4754-4762.

Wilkinson, J.M., Davies, D.R., 2013. The aerobic stability of silage: key findings and recent developments. Grass Forage Sci. 68, 1-19.

Winters, A.L., Fychan, R., Jones, R., 2001. Effect of formic acid and a bacterial inoculant on the amino acid composition of grass silage and on animal performance. Grass Forage Sci. 56, 181-192.

Yang, W.Z., Beauchemin, K.A., Rode, L.M., 2001. Effects of grain processing, forage to concentrate ratio, and forage particle size on rumen pH and digestion by dairy cows. J. Dairy Sci. 84, 2203-2216.

Yildirim, M., 2001. Purification of buchnericin LB produced by Lactobacillus buchneri LB. Turk. J. Biol. 25, 59-65.

Yildirim, Z., Avşar, Y.K., Yildirim, M., 2002. Factors affecting the adsorption of buchnericin LB, a bacteriocin produced by Lactobacillus buchneri. Microbiol. Res. 157, 103-107. 